\title{
MSX2 in ameloblast cell fate and activity
}

\author{
Sylvie Babajko ${ }^{1,2,3,4}$ *, Muriel de La Dure-Molla ${ }^{1,2,3,4,5}$, Katia Jedeon ${ }^{1,2,3,4}$ and Ariane Berdal ${ }^{1,2,3,4,5}$ \\ 'Laboratory of Molecular Oral Pathophysiology, Centre de Recherche des Cordeliers, Institut National de la Santé et de la Recherche Médicale, UMRS 1138, Paris, \\ France \\ ${ }^{2}$ Laboratory of Molecular Oral Pathophysiology, Centre de Recherche des Cordeliers, Université Paris-Descartes, Paris, France \\ ${ }^{3}$ Laboratory of Molecular Oral Pathophysiology, Centre de Recherche des Cordeliers, Université Pierre et Marie Curie-Paris, Paris, France \\ ${ }^{4}$ Laboratory of Molecular Oral Pathophysiology, Centre de Recherche des Cordeliers, Université Paris-Diderot, Paris, France \\ ${ }^{5}$ Centre de Référence des Maladies Rares de la Face et de la Cavité Buccale MAFACE, Hôpital Rothschild, Paris, France
}

\section{Edited by:}

Bernhard Ganss, University of

Toronto, Canada

\section{Reviewed by:}

David Clouthier, University of

Colorado Anschutz Medical

Campus, USA

Colin Robinson, University of Leeds, UK

${ }^{*}$ Correspondence:

Sylvie Babajko, Laboratory of

Molecular Oral

Pathophysiopathology, Centre de

Recherche des Cordeliers, Institut

National de la Santé et de la

Recherche Médicale, UMRS 1138,

15-21 rue de l'Ecole de Médecine,

75270 Paris 06, France

e-mail:sylvie.babajko@crc.jussieu.fr
While many effectors have been identified in enamel matrix and cells via genetic studies, physiological networks underlying their expression levels and thus the natural spectrum of enamel thickness and degree of mineralization are now just emerging. Several transcription factors are candidates for enamel gene expression regulation and thus the control of enamel quality. Some of these factors, such as MSX2, are mainly confined to the dental epithelium. MSX2 homeoprotein controls several stages of the ameloblast life cycle. This chapter introduces MSX2 and its target genes in the ameloblast and provides an overview of knowledge regarding its effects in vivo in transgenic mouse models. Currently available in vitro data on the role of MSX2 as a transcription factor and its links to other players in ameloblast gene regulation are considered. MSX2 modulations are relevant to the interplay between developmental, hormonal and environmental pathways and in vivo investigations, notably in the rodent incisor, have provided insight into dental physiology. Indeed, in vivo models are particularly promising for investigating enamel formation and MSX2 function in ameloblast cell fate. MSX2 may be central to the temporal-spatial restriction of enamel protein production by the dental epithelium and thus regulation of enamel quality (thickness and mineralization level) under physiological and pathological conditions. Studies on MSX2 show that amelogenesis is not an isolated process but is part of the more general physiology of coordinated dental-bone complex growth.

Keywords: MSX2, transcription factors, ameloblast, differentiation, enamel, teeth

\section{STRUCTURE AND MOLECULAR MECHANISMS OF MUSCLE SEGMENT HOMEOBOX (MsX) GENES HOMEOBOX GENES}

Msx2 is a member of the family of divergent homeoboxcontaining genes homologous to the Drosophila Muscle Segment Homeobox $(m s h)$ gene. Evolution including the duplication of the ancestral $m s h$ gene, has led to three different genes in mice and two in humans. Homeobox-containing genes share a wellconserved sequence of $183 \mathrm{bp}$ coding for a helix-loop-helix motif of 64 amino acids (Shirasawa et al., 1994). This homeodomain interacts with an A/T-rich DNA sequence thereby conferring transcriptional activity on the proteins carrying it (Gehring et al., 1994). Most homeobox genes are organized in clusters, and this is the case for $\operatorname{Hox} A, B, C$, and $D$ genes that control the development of the trunk spatially and temporally. Other homeobox genes, dispersed around the genome and classified as divergent homeogenes also include the Msx family which is crucial for the development of the head.

\section{MSX1 AND MSX2 ARE TRANSCRIPTIONAL REGULATORS}

The homeodomain of homeogenes Msx1 and Msx2 share 98\% sequence identity, such that they have similar transcriptional

Abbreviations: Bp, Base pairs; IEE, internal enamel epithelium. properties (Catron et al., 1996). MSX1 and MSX2 were first reported as transcriptional repressors (Catron et al., 1993, 1995), but their respective activities have not been precisely characterized. They are able to interact with a C/GTAATTG core consensus sequence (Catron et al., 1993). MSX homeoproteins may form either homodimers or heterodimers with other homeoproteins such as those encoded by Dlx (Zhang et al., 1997) and Pax genes (Bendall et al., 1999; Ogawa et al., 2006). The resulting competition for the same promoter sequence may explain, at least in part, their antagonist regulatory activities (Bendall and AbateShen, 2000). In addition to the presumed direct interactions via the homeodomain, their $\mathrm{N}$ - and $\mathrm{C}$-terminal domains are able to interact with other proteins and thereby also modulate transcription (Catron et al., 1995; Zhang et al., 1996). MSX2 is able to interact with SP3 (Bei, 2009) and with $\mathrm{C} / \mathrm{EBP} \alpha$, notably in ameloblasts (Zhou and Snead, 2000). Such physical interactions between MSX2 and C/EBP $\alpha$ enable switching of cell differentiation, as described for osteogenic/adipogenic differentiation in aortic myofibroblasts (Cheng et al., 2003). Transcriptional repression by MSX (reported for MSX1) is also modulated by interactions that drive the nuclear localization of the proteins, as shown for PIAS-1 (Lee et al., 2006) and H3K27me3 (Wang and Abate-Shen, 2012). These various papers show that the target selectivity of MSX1 and MSX2 and their transcriptional activities 
are dependent on the nature of the partners they interact with, via binding motifs located outside the homeodomain (Catron et al., 1995; Zhang et al., 1996). The sequence similarity between MSX1 and MSX2 in the N- and C-termini is lower (than in their homeodomains) and this presumably explains the different activities of the two factors. Transcriptional regulations of MSX2 depend on the nature of its partners: the specific combinations involved determine when, where and how the expression of the various MSX2-target genes is modulated.

\section{MSX1 AND 2 PRESENT REDUNDANT AND NON-REDUNDANT FUNCTIONS}

MSX functions are significant in morphogenesis in which specific developmental patterns control distinct stages and events. The involvement of MSX in morphogenesis was discovered in work with limb buds and ectodermal appendages such as teeth (Satokata and Maas, 1994; Houzelstein et al., 1997; Satokata et al., 2000). There are now a vast number of human and transgenic mouse gene mutations available (Table 1) providing evidence that both MSX1 and MSX2 are essential for skeletal morphogenesis and differentiation. The expression profiles of Msx homeobox genes may overlap; there may be redundancy between MSX1 and MSX2 as they display structural conservation, according to anatomical site (Sharpe, 1995). This is the case in limbs (and the resulting appendicular skeleton) but not in craniofacial morphogenesis and differentiation as illustrated by the selective phenotype of Msx mutants.

Non-redundant roles of MSX are exemplified in teeth. Both MSX1 and MSX2 are expressed as soon as dental lamina is initiated and their expression continues until the end of tooth formation, but in different areas (Thesleff, 2003). Transgenic mouse models have been used to characterize their respective function in dental development: MSX1 drives early tooth morphogenesis, whereas MSX2 is involved later in development (Bei et al., 2004; Thesleff, 2006). MSX1 gene mutations are associated with tooth agenesis in both human and mouse species (Vastardis et al., 1996; Houzelstein et al., 1997). Msx2 null mutants survive and display variable bone and dental phenotypes, especially in areas in which development is driven by epithelial-mesenchymal cell communications (Satokata et al., 2000). The different phenotypes associated with either MSX1 or MSX2 transgenic models strongly indicate that they do not have the same functions in tooth development; their respective molecular actions and partners need to be characterized.

\section{MSX2: A KEY ELEMENT OF THE TRANSCRIPTIONAL NETWORK DETERMINING AMELOBLAST GENE EXPRESSION AND AMELOBLAST LIFE-CYCLE MSX2, A KEY FACTOR FOR ENAMEL GENE EXPRESSION}

A number of studies have investigated the regulation of enamel gene transcription. They have identified a number of factors, including MSX2, controlling the transcription of enamel genes (Table 2). The amelogenin gene was the first to be studied because it encodes the most abundant enamel matrix protein. Amelogenin gene repression by MSX2 appears to be indirect through interaction with $\mathrm{C} / \mathrm{EBP} \alpha$ (Figure 1) (Zhou et al., 2000; Xu et al., 2007a). Interaction between MSX2 and $\mathrm{C} / \mathrm{EBP} \alpha$ abolishes the activating activity of $\mathrm{C} / \mathrm{EBP} \alpha$ on amelogenin transcription. MSX2/DLX heterodimers may also be involved in modulating amelogenin expression (Lézot et al., 2008). Indeed, DLX2 and DLX3 have been shown to control amelogenin expression (Lézot et al., 2008; Athanassiou-Papaefthymiou et al., 2011). The selective role of each DLX homeoprotein may be influenced by the other DLX family members expressed in ameloblasts (Lézot et al., 2008). MSX2 transcriptional modulations have been documented for other key enamel genes, notably those encoding enamel matrix proteins (enamelin and ameloblastin) and the two main proteases (MMP20 and KLK4) (Berdal et al., 1993; Molla et al., 2010). MSX2 is also able to repress the expression of calbindin$\mathrm{D}_{28 \mathrm{k}}$, a vitamin D-dependent calcium-handling protein, by direct interaction with its proximal promoter (Bolaños et al., 2012). Several partners of MSX2 identified in osteoblasts also influence ameloblast gene expression: for example, RUNX2 differentially regulates enamelin and Klk4 gene expression. Interestingly, its

Table 1 | MSX mutations in human and corresponding experimental models.

\begin{tabular}{|c|c|c|c|c|}
\hline & \multicolumn{2}{|l|}{ Human } & \multirow{2}{*}{$\begin{array}{l}\text { Mutant mice } \\
\text { Phenotype }\end{array}$} & \multirow[t]{2}{*}{ References } \\
\hline & Pathology & OMIM & & \\
\hline \multirow[t]{4}{*}{ MSX1 } & Ectodermal dysplasia 3, Witkop type & 189500 & Loss of function_(Msx1-/-) & \\
\hline & Orofacial cleft 5 & 608874 & Tooth agenesis, cleft palate & Satokata and Maas, 1994 \\
\hline & Tooth agenesis, with or without orofacial cleft & 106600 & & Houzelstein et al., 1997 \\
\hline & & & $\begin{array}{l}\text { Gain of function (transgenic mice) } \\
\text { craniofacial bone morphogenesis }\end{array}$ & Nassif et al., 2014 \\
\hline \multirow[t]{5}{*}{ MSX2 } & Loss of function & 168550 & Loss of function (Msx2-/-) & \\
\hline & Parietal foramina with cleidocranial dysplasia & & Bone defects & Satokata et al., 2000 \\
\hline & & & Tooth & $\begin{array}{l}\text { Aïoub et al., } 2007 \\
\text { Molla et al., } 2010\end{array}$ \\
\hline & Gain of function & 604757 & Gain of function (transgenic mice) & Liu et al., 1995 \\
\hline & Craniosynostosis, type 2 & & $\begin{array}{l}\text { Premature suture closure, } \\
\text { Ectopic cranial bone } \\
\text { Cardiovascular calcification }\end{array}$ & Shao et al., 2005 \\
\hline
\end{tabular}


Table 2 | Transcriptional regulations of the major enamel genes.

\begin{tabular}{|c|c|c|}
\hline Target genes & $\begin{array}{l}\text { Transcription } \\
\text { factors }\end{array}$ & References \\
\hline Amelogenin & $\begin{array}{l}\text { Msx2 } \\
\text { C/EBP } \alpha \\
\text { NF-Y } \nearrow \\
\text { C/EBP } \Delta \nearrow \\
\text { Dlx2 } \nearrow \\
\text { Dlx2 and FoxJ1 } \\
\text { Oct-1 } \\
\text { Pitx2 } \nearrow \\
\text { Clock genes } \nearrow \\
\text { Runx2 and } \\
\text { Dlx3 } \nearrow \\
\text { Tbx1 } \nearrow\end{array}$ & $\begin{array}{l}\text { Zhou et al., 2000; Xu et al., 2007a } \\
\text { Zhou and Snead, } 2000 \\
\text { Xu et al., } 2006 \\
\text { Xu et al., 2007b } \\
\text { Lézot et al., } 2008 \\
\text { Venugopalan et al., } 2011 \\
\text { Xu et al., 2010 } \\
\text { Li et al., 2013, 2014 } \\
\text { Lacruz et al., 2012a; Zheng et al., } \\
2013 \\
\text { Athanassiou-Papaefthymiou et al., } \\
2011 \\
\text { Mitsiadis et al., } 2008\end{array}$ \\
\hline Ameloblastin & Cbfa1 (Runx2) $\nearrow$ & Dhamija and Krebsbach, 2001 \\
\hline Enamelin & $\begin{array}{l}\text { B-catenin/LEF1 } \nearrow \\
\text { Runx2 } \searrow \text { and } \\
\text { Dlx3 } \nearrow\end{array}$ & $\begin{array}{l}\text { Tian et al., } 2010 \\
\text { Athanassiou-Papaefthymiou et al., } \\
2011\end{array}$ \\
\hline MMP20 & $\begin{array}{l}\text { Runx2 and } \\
\text { ODAM } \nearrow \\
\text { C-Jun (AP1) }\end{array}$ & $\begin{array}{l}\text { Lee et al., } 2010 \\
\text { Zhang et al., } 2007\end{array}$ \\
\hline KLK4 & $\begin{array}{l}\text { Clock genes } \nearrow \\
\text { Runx2 } \nearrow \text { and } \\
\text { Dlx3 } \nearrow\end{array}$ & $\begin{array}{l}\text { Zheng et al., } 2013 \\
\text { Athanassiou-Papaefthymiou et al., } \\
2011\end{array}$ \\
\hline
\end{tabular}

own expression is up-regulated by NR1D1 which expression is also controlled by clock genes (Athanassiou-Papaefthymiou et al., 2011) establishing a complex network of direct and indirect controls by circadian transcription factors. Thus, clock proteins (BMAL1, Clock, PER1, and PER2) may regulate enamel gene expression either directly (Lacruz et al., 2012a; Zheng et al., 2013) or indirectly via NR1D1 and consequently MSX2. ODAM expression is also up-regulated by RUNX2, and ODAM increases $M m p 20$ expression with its promoter activity (Lee et al., 2010). In view of the relationship between MSX2 and RUNX2, it may be possible that MSX2 also modulates Mmp20 expression.

In addition, as evidenced in early development, Msx2 expression itself may be controlled either directly or indirectly via enamel proteins. This was demonstrated by in vivo and in vitro studies showing a feedback loop between ameloblastin and Msx2 expression (Fukumoto et al., 2004; Sonoda et al., 2009). However, the best characterized positive feedback loop involving MSX2 and a secreted protein is that operating with BMP4: BMP4 induces Msx2 expression and in turn, MSX2 controls Bmp4 (Bei and Maas, 1998) (Figure 2). Indeed, the Msx2 promoter contains a BMP-responsive enhancer element (Brugger et al., 2004) and the Bmp4 promoter contains an Msx (1 and 2) responsive element (Wang et al., 2011).

Considering the redundancies between Msx1 and Msx2, it is interesting to raise the question of similar expression modulations

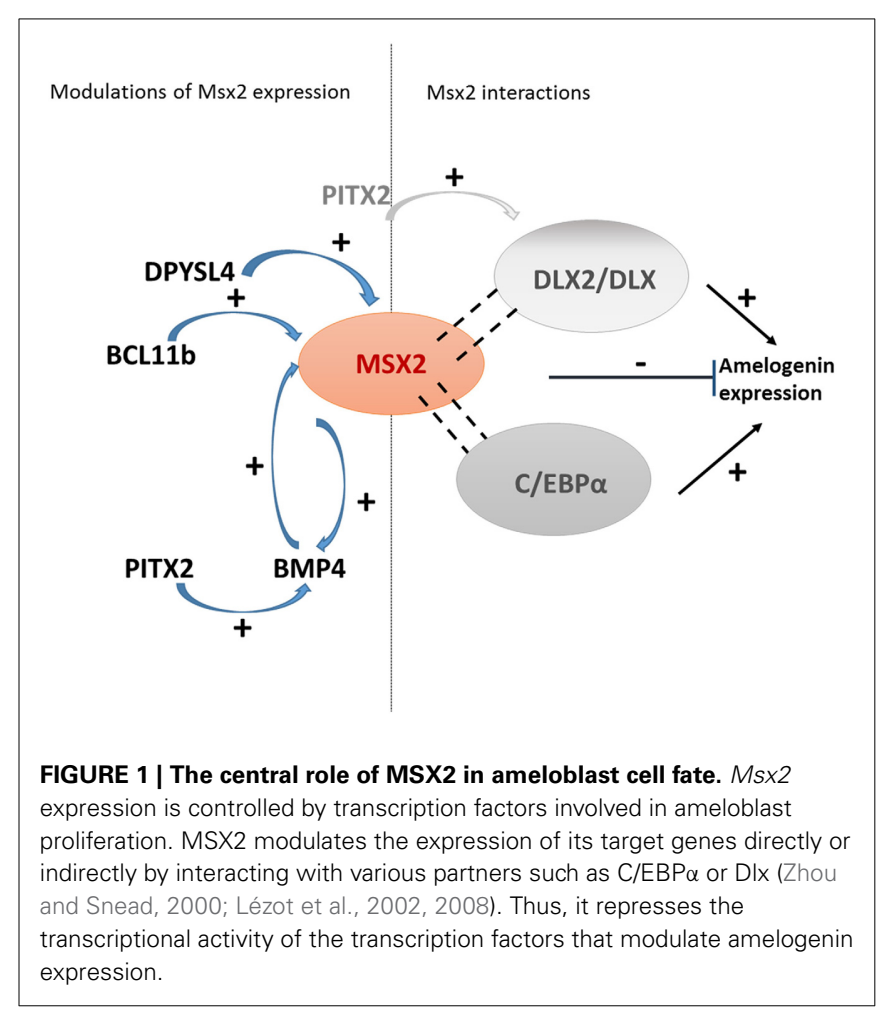

for Msx2 compared to those already reported for Msx1. Also, the level of Msxl protein is regulated by its own antisense RNA: the Msxl gene is transcribed in both directions producing, in addition to the sense transcript, a long endogenous antisense noncoding RNA (Blin-Wakkach et al., 2001). This RNA is believed to provide fine control of MSX1 homeoprotein quantities during development (Coudert et al., 2005) via post-transcriptional sense RNA decay (Petit et al., 2009) and thus influence MSX1 protein activity (Babajko et al., 2009). Number of Hox homeogenes are submitted to bi-directional transcription (Mainguy et al., 2007); similar events that need to be investigated may also control Msx2 expression.

In conclusion, Msx2 expression is modulated either directly by various intracellular factors or indirectly by secreted factors, resulting in fined tuned levels of MSX2 that control enamel gene expression and ameloblast cell fate.

\section{Msx2 IS INVOLVED IN CELL PROLIFERATION}

MSX2 is present throughout the process of ameloblast differentiation/maturation although its expression decreases during the secretory stage and may modulate enamel gene expression differently depending on the combination of transcription factors present (Figure 2). Very few studies report gene expression modulations during the maturation stage (Lacruz et al., 2012b), such that the function of MSX2 during the terminal differentiation of ameloblasts is less clear.

Msx2 is not only expressed in the inner dental epithelium but throughout the entire enamel organ as evidenced in the rodent apical loop (Jiang and Wang, 2010). In Msx2-/- mouse dental epithelium, proliferation of stellate reticulum cells and stratum 


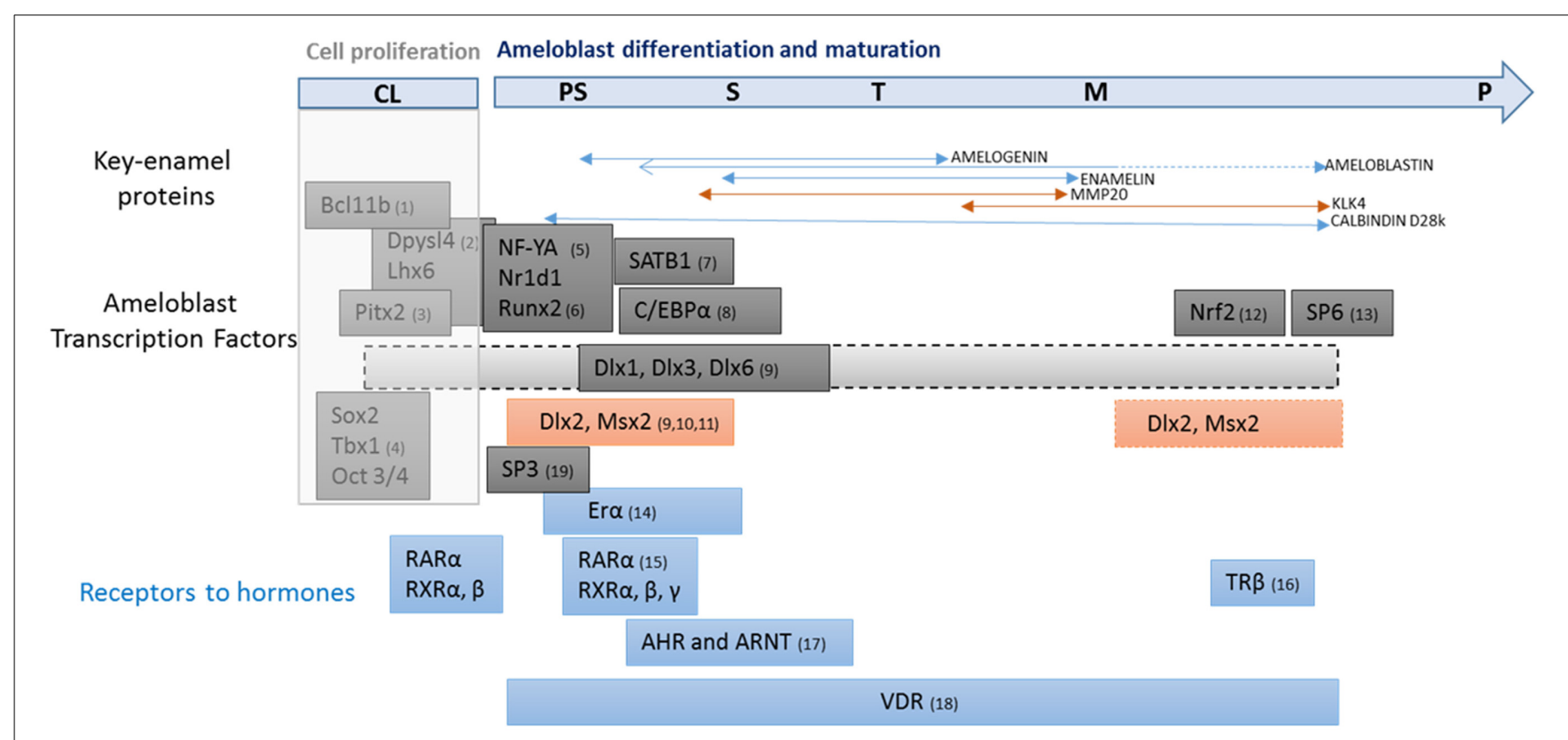

FIGURE 2 | Transcription factors involved in ameloblast proliferation, differentiation and maturation. Transcription factors involved in ameloblast proliferation and differentiation (in black), and hormonal response (in blue). Enamel gene patterns are linked to presecretion, secretion and maturation stages of amelogenesis. The first key-point is the transition from presecretion to secretion stage during which differentiated ameloblasts acquire all the properties required for orderly secretion of enamel proteins (amelogenin, enamelin, amelobastin, and calbindin- $\mathrm{D}_{28 \mathrm{k}}$ ). A subsequent key-point for amelogenesis is the second transition from secretion to post-secretion. This event determines final enamel thickness via an abrupt decrease in matrix protein production. Enamel mineral quality is also conditioned by this transition associated with massive cell apoptosis and size reduction. Ameloblasts show an abrupt increase in the production of proteins involved in the mineralization process, including MMP20 and KLK4 proteases, mineral-handling effectors such as Ca-ATPase, alkaline phosphatase, proton pumps, carbonic anhydrase, calbindin- $D_{28}$, and tight junction elements which contribute to enamel maturation. The list of up- and down-regulated genes at these two key stages of amelogenesis is emerging from current "omics" studies and most of them have been identified. The challenge now will be to integrate these effectors and their regulators into a model that describes the resulting enamel quality. CL, cervical loop; PS, pre-secretion; $\mathbf{S}$ secretion; $\mathbf{T}$, transition; $\mathbf{M}$, maturation stages and $\mathbf{P}$, pigmentation. (1, Golonzhka et al., 2009; 2, Yasukawa et al., 2013; 3, Cao et al., 2013; 4, Catón et al., 2009; 5, Xu et al., 2007a; 6, Athanassiou-Papaefthymiou et al., 2011; 7, Stahl et al., 2013; 8, Zhou and Snead, 2000; 9, Lézot et al., 2008; 10, Bei et al., 2004; 11, Molla et al., 2010; 12, Yanagawa et al., 2004; 13, Muto et al., 2012; 14, Ferrer et al., 2005; 15, Bloch-Zupan et al., 1994; 16, Lacruz et al., 2012b; 17, Sahlberg et al., 2002; 18, Davideau et al., 1996; 19, Bei, 2009). intermedium cells increases. At these early stages, Msx2 expression is induced by the key transcription factors, DPYSl4 and BCL11b (Ctip2), also determinant of cell proliferation (Figures 1, 2) (Golonzhka et al., 2009; Yasukawa et al., 2013). Msx2 expression and Dlx2 expression are also indirectly up-regulated by PITX2 via BMP4, which are also expressed in proliferative cells (Venugopalan et al., 2011; Cao et al., 2013) (Figure 1). As a result of the various $M s x 2$ expression modulations by early factors, $M s \times 2$ is expressed in undifferentiated inner enamel epithelial (IEE) cells and down-regulated when ameloblast cells overtly differentiate (Mackenzie et al., 1991, 1992; Maas and Bei, 1997).

\section{LESSONS FROM NON-CONDITIONAL MsX2 MUTANTS - STRENGTHS AND LIMITATIONS}

Most of the data described above result from in vitro studies. However, in vivo models are also informative about MSX2 function because they include cell-cell communications.

\section{Msx2-/- MOUSE DENTAL PHENOTYPE ILLUSTRATES THE PLEIOTROPIC ROLE PLAYED BY Msx2}

At this time, several targets have been identified in enamel within their physiological context. Dental morphogenesis in Msx2-/- mice is abnormal: cusp generation is affected by enamel knot disorganization (Figure 3D) (Bei et al., 2004); defects are observed in the enamel (Molla et al., 2010) and other dental tissues; and roots are malformed with the root epithelium overexpressing enamel proteins, especially amelogenins and ameloblastin. Also, jaw osteoclast activity is decreased locally around the dental follicle; eruption failure and pseudo-odontogenic tumor deviation of the tooth germs culminate in the third mandibular molars (Aïoub et al., 2007). This phenotype is coherent with the pattern of Msx2 expression in many cells forming the tooth and periodontal bone. Indeed, its expression starts from the very beginning of odontogenesis, first in the ectoderm and mesoderm from the gastrulation stage, and subsequently in neural crest cells and oral epithelium (Bendall and Abate-Shen, 2000). During root formation, Msx2 is again expressed in epithelial cells (Hertwig root sheath and later epithelial Malassez rests) as well as in dental and periodontal mesenchyme (Yamashiro et al., 2003; Molla et al., 2010). As alveolar bone and tooth development are linked, it is important to note that differentiating and differentiated osteoblasts express Msx2 (Dodig et al., 1996; Mirzayans et al., 2012). Finally, peridental osteoclasts express Msx2 and do so with regional gradients related to both dental crown and root growth (Aïoub et al., 2007) (Figure 3). 


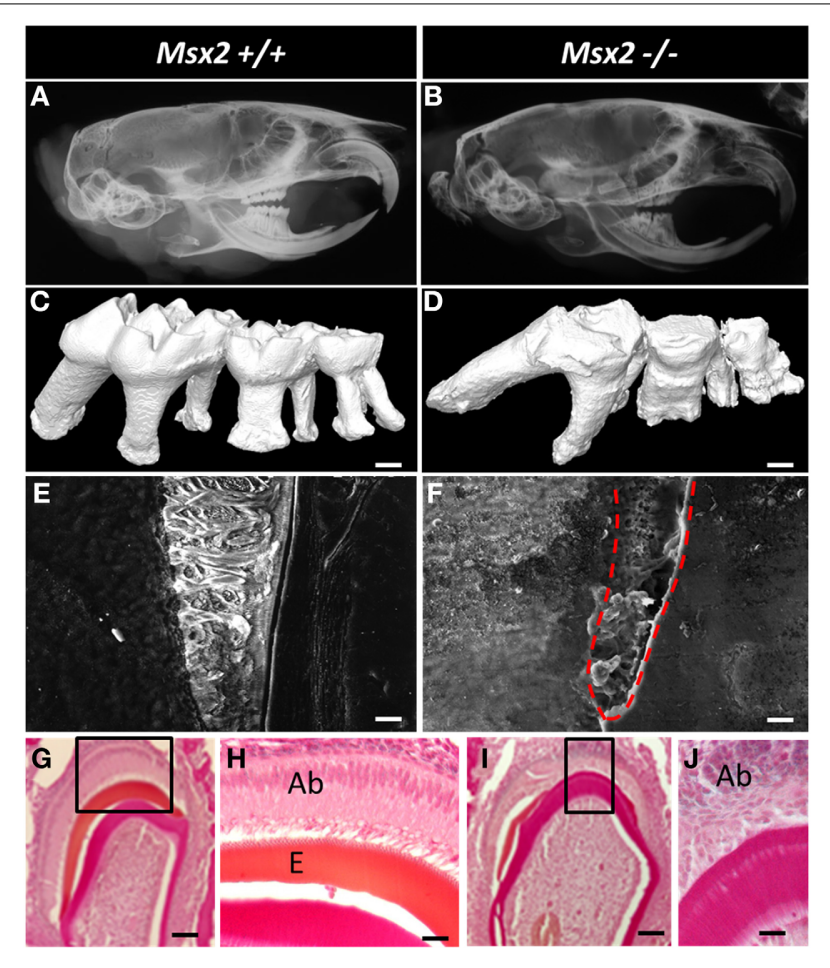

FIGURE 3 | Dental phenotype of Msx2-I- mice with reference to wild-type animals $(\boldsymbol{M s x} \mathbf{2}+/+)$. (A,B) Microradiographs of the whole heads of 3-month old mice showing craniofacial and teeth dysmorphology; indeed craniofacial morphogenesis is under the control of MSX2 (Simon et al., 2014). Msx2-/- mutant mice present a non-isometric overall craniofacial size decrease; the teeth exhibit crown and root dysmorphology with altered enamel, enlargement of the pulp cavity, short and curved roots with abnormal orientations, and reduced curvature of the incisor. The third molar showed impaired eruption and the most severe phenotype. (C,D) 3D reconstruction of mouse molars revealed the absence of cuspid relief and severe generalized enamel hypoplasia with irregular surface. Msx2-1mice displayed complex radicular morphology (Aïoub et al., 2007). (E,F) Scanning electron microscopy of the first molar mandible illustrates a severe reduction in enamel thickness. Enamel in Msx2-1- animals shows the absence of enamel prisms, replaced by an amorphous layer (Molla et al., 2010); scale bars: $10 \mu \mathrm{m}$. (G-J) Histological analysis of mouse molar enamel reveals hypoplastic amelogenesis imperfecta in Msx2-1- mice. This feature is related, after a correct ameloblast differentiation process, to a secondary inability of ameloblasts to secrete the enamel matrix which would mineralize. Ameloblast cells in these animals lose their polarization, become rounded and isolated, and finally disappear (Ab, ameloblast; $\mathrm{E}$, enamel —scale bars: G, I: $100 \mu \mathrm{m} ; \mathbf{H}, \mathbf{J}: 40 \mu \mathrm{m})$.

In summary, all cells associated with the complex formed by tooth and bone express the Msx2 gene during their lifetime, and do so with exquisitely precise timing and levels. This makes it difficult to directly anticipate MSX2 function in one tissue (in vivo) from data obtained in vitro. For example, in the periodontal ligament cells, MSX2 prevents osteo-differentiation in vitro (Yoshizawa et al., 2004) while bona fide ankylosis is not found in Msx2-/- mice (Aioub et al., 2007). A thorough analysis of MSX2 function in tooth/bone inter-dependent development requires a number of conditional gene mutations or misexpressions in each MSX2-target cell, each corresponding to different restricted temporal windows and finely defined levels of expression. A complementary strategy has been used to rescue osteoclast activity in non-conditional Msx2-I- mice by mating $M s \times 2-1-$ mice with a transgenic mouse line overexpressing RANK (Tnfrsf11a), the main osteoclastic-differentiating factor (Castaneda et al., 2013). This allowed the impact of one-cell processes (resorption) on tooth and bone complex formation to be specified and described.

\section{Msx2 CONTROLS MORPHOGENESIS VIA EPITHELIAL Bmp4 LEVELS AND THE ASSOCIATED DEATH PROGRAM IN ENAMEL KNOT}

Early tooth development in Msx2 null mice is normal, and only a small number of effectors are modified: epithelial Bmp4 expression decreases whereas expressions of $\mathrm{Fgf4}$, the cyclin-dependent kinase (cdk) inhibitor gene $\mathrm{p} 21$, and Shh are not modified (Bei et al., 2004). Furthermore, Bmp4 expression is not altered in the mesenchymal compartment. MSX2 intervenes in epithelialmesenchymal cross-talk, leading to odontogenesis. Mesenchymal BMP4 stimulates Msx2 and Cdk p21 expression in the enamel knot; MSX2 in turn stimulates Bmp4 expression in epithelial cells. MSX2 in vitro cooperates in the BMP4-mediated programmed cell death pathway (Israsena and Kessler, 2002), and Msx2 overexpression stimulates Bmp4 increasing apoptosis (Marazzi et al., 1997; Wu et al., 2003). Thus, the regulatory loop initiated by MSX2 is determinant for dental cell signaling and communication and consequently tooth morphogenesis.

\section{ALTERED LAMININ $5 \alpha 3$ PATTERNS AFFECT AMELOBLAST INTEGRITY}

In the dental epithelium, laminin $5 \alpha 3$ is expressed in the basal membrane prior to ameloblast differentiation and disappears when cells differentiate (Yoshiba et al., 1998). It has been described as being distributed in a "membrane like" structure localized between the stratum intermedium and ameloblast cell layer. In Msx2-/- mice, ameloblasts are able to achieve terminal differentiation but the integrity of their junctional complexes is affected. In the absence of MSX2, the inner dental epithelium presents rounded and detached ameloblasts with loose intercellular junctions (Bei et al., 2004; Molla et al., 2010) (Figure 4). Laminin $5 \alpha 3$ expression is lower than in wild-type animals, whereas the expression of E-cadherin, $\beta$-catenin, and the integrin subunits $\alpha 5 \beta 5$ and $\alpha 6 \beta 4$ remains unchanged (Bei et al., 2004; Molla et al., 2010). Thus, the MSX2 target gene laminin $5 \alpha 3$ may control the formation of cell-cell-junctions and thus organization of the ameloblastic layer (Zhou et al., 1999). This possibility is supported by a LAMA5 gene mutation in the epidermolysis bullosa characterized by skin fragility and enamel dysplasia (Brooks et al., 2008), as a result of the destruction of dermal and dental epithelia, respectively.

\section{PROSPECTS FOR EXPERIMENTAL MODELS-FROM DISCRETE TO CONTINUOUS PARAMETERS OF ENAMEL QUALITY CONTROL}

THE PHYSIOLOGICAL CONDITIONS ARE ONLY PARTLY REPRODUCED IN VITRO

There have been reported successful in vitro promoter studies in ameloblasts (see above) thanks to establishment of cell models that help to decipher molecular mechanisms (Zhou and Snead, 2000; Zhou et al., 2000; Xu et al., 2007a). However, 

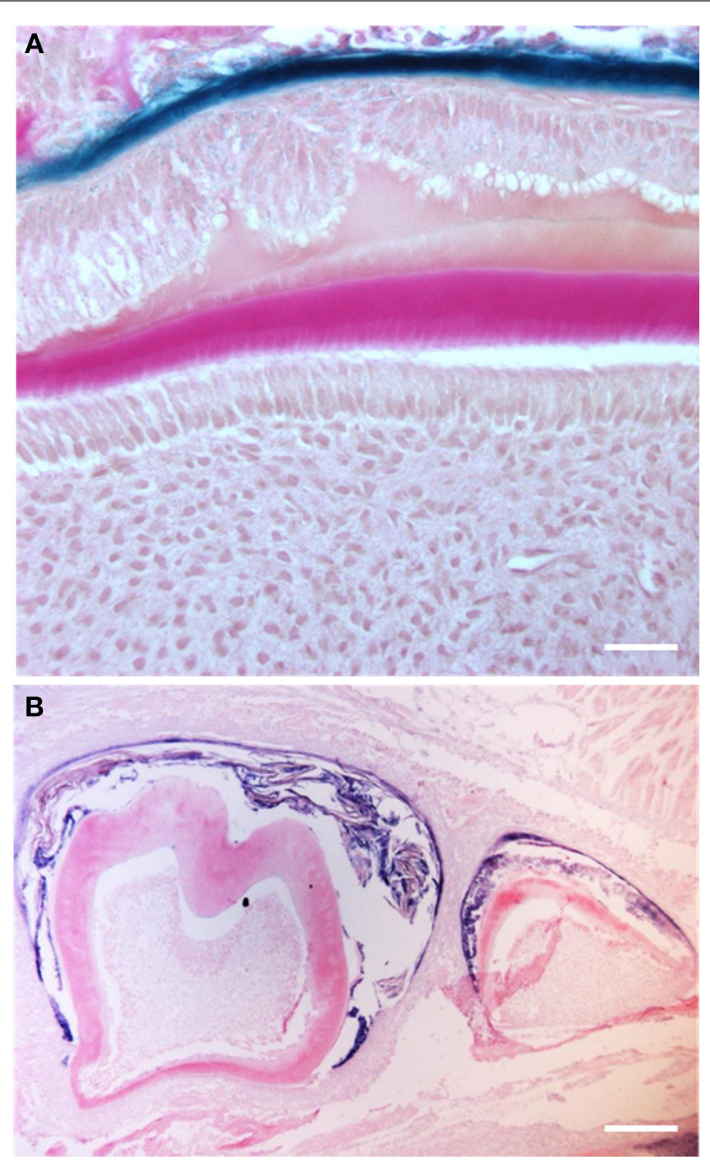

FIGURE 4 | Amelogenin production in 21-day old Msx2-/- mice showing ameloblast cell secretory disorders in more detail (Molla et al., 2010). In this condition, the polarity of the entire enamel organ is completely lost. (A) Epithelial cells appear to delaminate losing their orientation and intercellular cohesion (scale bars: $20 \mu \mathrm{m}$ ). (B) The apparent level of amelogenin RNA synthesis is uniformly low in the entire enamel organ. The resulting ameloblasts do not produce significant amounts of enamel matrix (scale bars: $100 \mu \mathrm{m}$ ).

the transcriptional program leading to ameloblast activity during enamel presecretion, secretion, and post-secretion is only progressively emerging (Lacruz et al., 2012b; Simmer et al., 2014) (Figure 2). Indeed, the spatial and temporal program of enamel formation is not recapitulated in cell cultures. Five factors are more or less reproduced in current cell culture models: (1) Epithelial organization and ameloblast polarity. (2) Signals produced by non ameloblastic cells (enamel knot, stratum intermedium and mesenchymal odontoblasts) which drive ameloblast fate and activity. Indeed, epithelial-mesenchymal interaction has been demonstrated in ameloblasts co-cultured with odontoblasts (Matsumoto et al., 2011). (3) Key stages of presecretion, secretion and post-secretion related to up- and down-regulation of matrix protein levels and protease activities (Figure 2). (4) The delicate crystal and prism architecture which requires significant and ordered enamel matrix deposition and biomineralization. (5) An appropriate peridental microenvironment in which bone apposition and resorption rates may influence enamel formation.
Indeed, allometric tooth growth is dependent on (and reversely determines) eruption rate (Castaneda et al., 2011, 2013).

\section{THE RODENT INCISOR, AN “IN VIVO TEST TUBE" FOR ANALYZING GENE AND ENVIRONMENT INTERACTIONS IN ENAMEL}

Various experimental approaches have been developed including organotypic cultures (Bronckers, 1983; Bronckers et al., 2009), primary cultures (DenBesten et al., 2005), and hybrid cell cultures (Matsumoto et al., 2011; Jiang et al., 2014). In vivo studies may involve dissections under a microscope which is either manual or, more recently, by laser-capture (Jacques et al., 2014). For growthlimited teeth (three non-renewed molars in rodents), amelogenesis follow-up requires animals of different ages, increasing the sample size required (Onishi et al., 2008). Rodent incisor enamel displays an exceptionally simple structure and is reasonably large. Its continuous growth facilitates the exploration of enamel formation under defined conditions and during defined temporal windows (transgenic mice, environmental, and systemic disturbances) at any animal age (Damkier et al., 2014). The course of amelogenesis is spatially distributed along the longitudinal axis of the tooth. Consequently, extracellular cascades of peptide-peptide and mineral interactions can be sampled along the longitudinal axis of single rodent incisors (Jedeon et al., 2013), and ameloblasts and changing enamel matrix are easily followed (Houari et al., 2014). Protein and mRNA studies are feasible and have included comparisons between incisor samples from test and control conditions in rats (Berdal et al., 1993; Jedeon et al., 2013) and mice (Descroix et al., 2010; Molla et al., 2010).

\section{MSX2 IS A MORPHOGEN FOR ENAMEL, CONTROLLING ITS THICKNESS}

The murine incisor "in vivo test tube" has been used in studies of MSX2 in differentiated ameloblasts. Msx2 heterozygous $(M s \times 2+/-)$ mice are a unique model for investigating MSX2 dose effects. Ameloblasts survive and differentiate appropriately in $M s \times 2+1-$ mice (unlike those in $M s \times 2-1-$ mice) and the amounts of Ms $22 \mathrm{mRNA}$ are half those in wild-type mice. Enamel gene studies have revealed a specific overabundance of amelogenin mRNA in $M s x 2+/-$ mice. The enamel phenotype in $M s \times 2+/-$ mice included increased thickness and, more specifically, a thicker outer prismatic enamel layer and larger prism diameter (Molla et al., 2010; Figure 5). This suggests that MSX2 determines enamel thickness in vivo. Indeed, a rigorous analysis of the pattern of $M s x 2$ expression during the secretion stage revealed a inverse relationship between Msx2 mRNA levels and enamel thickness (Molla et al., 2010) as similarly described for enamel thickness and amelogenin levels (Snead et al., 1988). This is also the case for DLX2 (Lézot et al., 2008) in which an inverse correlation between DLX2 levels and thickness was shown through quantitative measurements of incisors. Also, decreased production of enamel proteins during the enamel maturation stage is associated with a significant up-regulation of Msx2 (Figure 5), in accordance with in vitro data showing the MSX2 transcriptional repression of amelogenin expression. On the contrary, ameloblast alterations observed in Msx2-/- mice result in deficient enamel protein production (especially amelogenin) and result in hypoplastic enamel without visible prismatic structures (Molla et al., 2010_-see Figure 3F). 


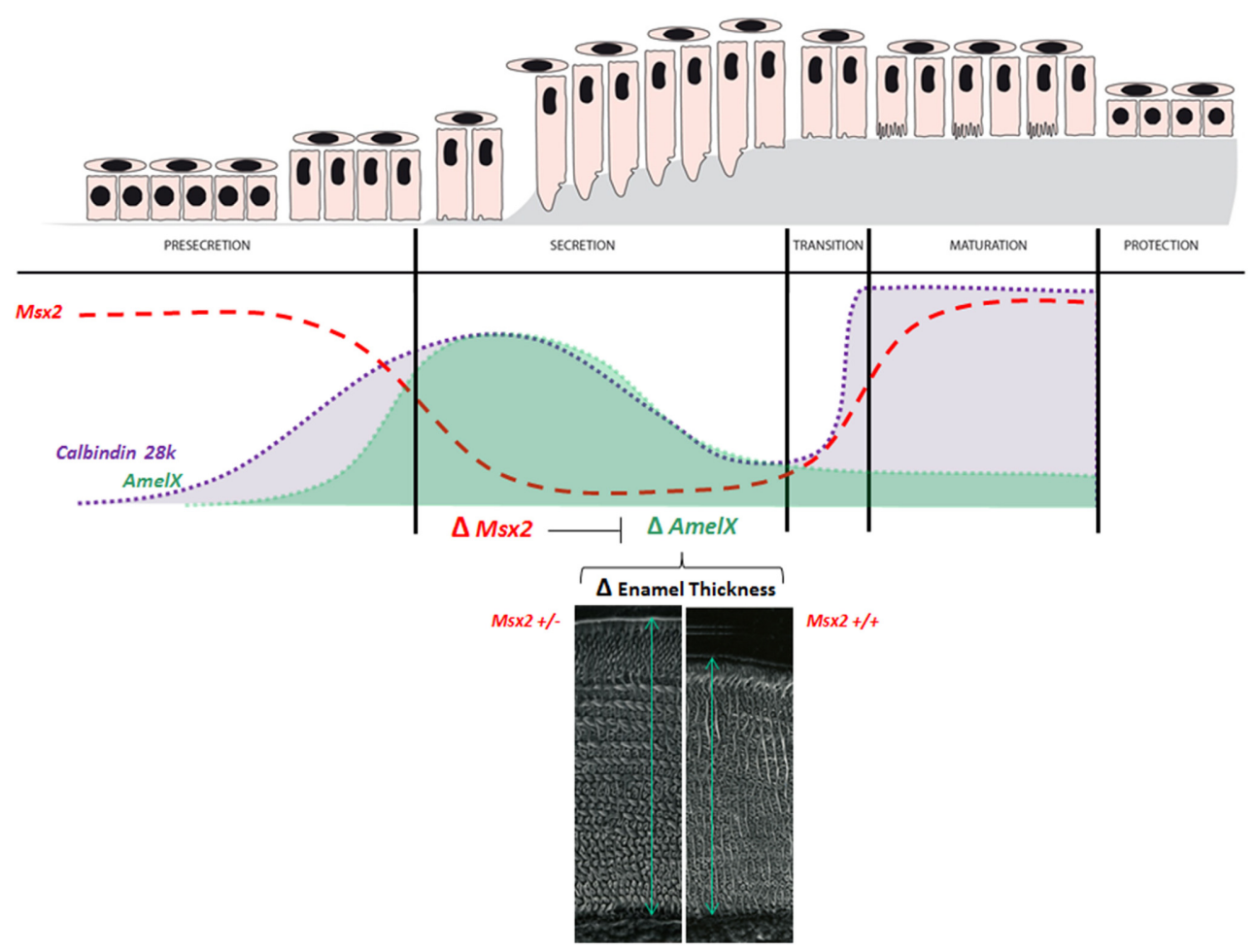

FIGURE 5 | Physiological levels of MSX2 and its target-genes, amelogenin and calbindin- $\mathbf{D}_{\mathbf{2 8 k}}$. Msx2 expression during the ameloblast life-cycle is inversely related to amelogenin abundance. The figure is a compilation of published findings (Molla et al., 2010) and illustrates two significant examples of gene expression level fluctuations (amelogenin-green; and calbindin- $\mathrm{D}_{28 \mathrm{k}}$ - gray) in ameloblasts during amelogenesis and their relationships with $M s \times 2$ expression (red). (1) The presecretion/secretion/maturation sequence. Msx2 down-regulation is related to down-regulation of amelogenin and calbindin- $D_{28 \mathrm{k}}$ from the presecretion stage to the secretion stage. (2) During the secretion stage controlling enamel thickness; amelogenin mRNA production in ameloblasts depends on their sites or localization (Snead et al., 1988), leading to the differing thickness of enamel across the tooth. The patterns of $M s \times 2$ and D/x2 expression are the converse of that of amelogenin (Lézot et al., 2008). We established that MSX2 indeed contributes to enamel thickness inhibition in vivo (Molla et al., 2010). Enamel thickness as determined by scanning electron microscopy in mandible incisor of 3-month old mice is greater under Msx2 haploinsufficiency than in controls (here $M s \times 2+/-$ compared to wild-type $M s \times 2+/+$ mice). This $M s \times 2$ haploinsufficiency is also associated with overexpression of both amelogenin (Molla et al., 2010) and calbindin- $\mathrm{D}_{28 \mathrm{k}}$ (Bolaños et al., 2012). The relationship between calbindin- $D_{28 k}$ and MSX2 is more complex because calbindin- $\mathrm{D}_{28 \mathrm{k}}$ abundance abruptly increases for a second time during the maturation stage. However, the partners of MSX2 at this stage are still unknown and its activity on gene expression has not been extensively investigated.

\section{CONCLUSION}

Integrative physiological networks underlying amelogenesis are just emerging. Experimental progress in the field of enamel has mainly been based on gene disrupting strategies to describe developmental circuits which drive enamel formation. However, only precise quantitative and continuous studies allow appropriate analysis of the interplays that determine enamel thickness and quality. This is the case for studies addressing the constitutive regulation of ameloblast activity, illustrated here by the MSX and DLX homeoprotein pathways. They provide clues on how enamel acquires differential thickness depending on its anatomical location. They modulate expression of key genes involved in amelogenesis (Lézot et al., 2002, 2008; Molla et al., 2010; Bolaños et al., 2012). It is thus very likely that these factors are able to transmit effects of many environmental factors, whether regional or systemic (including the availability of calcium, vitamin D, fluoride, or even pollutants) that also affect the final enamel composition and quality (Berdal et al., 1993; Jedeon et al., 2013; Houari et al., 2014).

In summary, the dental cell and enamel system illustrates how MSX homeoproteins may be reiteratively enrolled in a single organ. Throughout the cell life-cycle, cooperation between particular transcription factors in a stage-specific manner controls the expression of a number of genes. Such MSX2-target genes encode growth factors, junctional complexes, matrix proteins, and other proteins involved in enamel mineralization. Consistent with reiterative up- and down-regulations, MSX2 drives particular events; some in early development, some during growth and, finally, some in conditions of homeostasis in adults with the effect decreasing with age. MSX2 is exemplary of the integrative schemes of a single transcription factor making multiple contributions to the physiological or pathological development of complex organs, composed of many cells of different types, as described here in the dental-bone complex. 


\section{FUNDING}

This work was funded by the University Paris-Diderot, the French National Institute of Health and Medical Research (INSERM) and the National Research Agency (ANR): OSTEODIVERSITY (SVSE 1-2012).

\section{REFERENCES}

Aïoub, M., Lézot, F., Molla, M., Castaneda, B., Robert, B., Goubin, G., et al. (2007). Msx2 - / - transgenic mice develop compound amelogenesis imperfecta, dentinogenesis imperfecta and periodental osteopetrosis. Bone 41, 851-859. doi: 10.1016/j.bone.2007.07.023

Athanassiou-Papaefthymiou, M., Kim, D., Harbron, L., Papagerakis, S., Schnell, S., Harada, H., et al. (2011). Molecular and circadian controls of ameloblasts. Eur. J. Oral Sci. 119(Suppl. 1), 35-40. doi: 10.1111/j.1600-0722.2011.00918.x

Babajko, S., Petit, S., Fernandes, I., Méary, F., LeBihan, J., Pibouin, L., et al. (2009). Msxl expression regulation by its own antisense RNA: consequence on tooth development and bone regeneration. Cells Tissues Organs 189, 115-121. doi: $10.1159 / 000151748$

Bei, M. (2009). Molecular genetics of ameloblast cell lineage. J. Exp. Zool. B Mol. Dev. Evol. 312B, 437-444. doi: 10.1002/jez.b.21261

Bei, M., and Maas, R. (1998). FGFs and BMP4 induce both Msx1-independent and Msxl-dependent signaling pathways in early tooth development. Development 125, 4325-4333.

Bei, M., Stowell, S., and Maas, R. (2004). Msx2 controls ameloblast terminal differentiation. Dev. Dyn. 231, 758-765. doi: 10.1002/dvdy.20182

Bendall, A. J., and Abate-Shen, C. (2000). Roles for Msx and Dlx homeoproteins in vertebrate development. Gene 247, 17-31. doi: 10.1016/S0378-1119(00)00081-0

Bendall, A. J., Ding, J., Hu, G., Shen, M. M., and Abate-Shen, C. (1999). Msx1 antagonizes the myogenic activity of Pax3 in migrating limb muscle precursors. Development 26, 4965-4976.

Berdal, A., Hotton, D., Pike, J. W., Mathieu, H., and Dupret, J. M. (1993). Celland stage-specific expression of vitamin D receptor and calbindin genes in rat incisor: regulation by 1,25-dihydroxyvitamin D3. Dev. Biol. 155, 172-179.

Blin-Wakkach, C., Lezot, F., Ghoul-Mazgar, S., Hotton, D., Monteiro, S., Teillaud, C., et al. (2001). Endogenous Msxl antisense transcript: in vivo and in vitro evidences, structure, and potential involvement in skeleton development in mammals. Proc. Natl. Acad. Sci. U.S.A. 98, 7336-7341. doi: 10.1073/pnas.131497098

Bloch-Zupan, A., Décimo, D., Loriot, M., Mark, M. P., and Ruch, J. V. (1994). Expression of nuclear retinoic acid receptors during mouse odontogenesis. Differentiation 57, 195-203. doi: 10.1046/j.1432-0436.1994.5730195.x

Bolaños, A., Hotton, D., Ferbus, D., Loiodice, S., Berdal, A., and Babajko, S. (2012). Regulation of calbindin-D (28k) expression by Msx2 in the dental epithelium. J. Histochem. Cytochem. 60, 603-610. doi: 10.1369/0022155412450641

Bronckers, A. L. (1983). Effect of oxygen tension on matrix formation and mineralization in hamster molars during development in vitro. J. Biol. Buccale 11, 195-207.

Bronckers, A. L., Lyaruu, D. M., and DenBesten, P. K. (2009). The impact of fluoride on ameloblasts and the mechanisms of enamel fluorosis. J. Dent. Res. 88, 877-893. doi: 10.1177/0022034509343280

Brooks, J. K., Bare, L. C., Davidson, J., Taylor, L. S., and Wright, J. T. (2008). Junctional epidermolysis bullosa associated with hypoplastic enamel and pervasive failure of tooth eruption: oral rehabilitation with use of an overdenture. Oral Surg. Oral Med. Oral Pathol. Oral Radiol. Endod. 105, e24-e28. doi: 10.1016/j.tripleo.2007.12.038

Brugger, S. M., Merrill, A. E., Torres-Vazquez, J., Wu, N., Ting, M. C., Cho, J. Y., et al. (2004). A phylogenetically conserved cis-regulatory module in the Msx2 promoter is sufficient for BMP-dependent transcription in murine and Drosophila embryos. Development 131, 5153-5165. doi: 10.1242/dev.01390

Cao, H., Jheon, A., Li, X., Sun, Z., Wang, J., Florez, S., et al. (2013). The Pitx2: miR-200c/141:noggin pathway regulates Bmp signaling and ameloblast differentiation. Development 140, 3348-3359. doi: 10.1242/dev.089193

Castaneda, B., Simon, Y., Ferbus, D., Robert, B., Chesneau, J., Mueller, C., et al. (2013). Role of RANKL (TNFSF11)-dependent osteopetrosis in the dental phenotype of Msx2 null mutant mice. PLOS ONE 8:e80054. doi: 10.1371/journal.pone.0080054

Castaneda, B., Simon, Y., Jacques, J., Hess, E., Choi, Y. W., Blin-Wakkach, C., et al. (2011). Bone resorption control of tooth eruption and root morphogenesis: involvement of the receptor activator of NF-кB (RANK). J. Cell. Physiol. 226, 74-85. doi: 10.1002/jcp. 22305

Catón, J., Luder, H. U., Zoupa, M., Bradman, M., Bluteau, G., Tucker, A. S., et al. (2009). Enamel-free teeth: Tbxl deletion affects amelogenesis in rodent incisors. Dev. Biol. 328, 493-505. doi: 10.1016/j.ydbio.2009.02.014

Catron, K. M., Iler, N., and Abate, C. (1993). Nucleotides flanking a conserved TAAT core dictate the DNA binding specificity of three murine homeodomain proteins. Mol. Cell. Biol. 13, 2354-2365.

Catron, K. M., Wang, H., Hu, G., Shen, M. M., and Abate-Shen, C. (1996). Comparison of MSX-1 and MSX-2 suggests a molecular basis for functional redundancy. Mech. Dev. 55, 185-199.

Catron, K. M., Zhang, H., Marshall, S. C., Inostroza, J. A., Wilson, J. M., and Abate, C. (1995). Transcriptional repression by Msx-1 does not require homeodomain DNA-binding sites. Mol. Cell. Biol. 15, 861-871.

Cheng, S. L., Shao, J. S., Charlton-Kachigian, N., Loewy, A. P., and Towler, D. A. (2003). MSX2 promotes osteogenesis and suppresses adipogenic differentiation of multipotent mesenchymal progenitors. J. Biol. Chem. 278, 45969-45977. doi: 10.1074/jbc.M306972200

Coudert, A. E., Pibouin, L., Vi-Fane, B., Thomas, B. L., Macdougall, M., Choudhury, A., et al. (2005). Expression and regulation of the Msx1 natural antisense transcript during development. Nucleic Acids Res. 33, 5208-5218. doi: 10.1093/nar/gki831

Damkier, H. H., Josephsen, K., Takano, Y., Zahn, D., Fejerskov, O., and Frische, S. (2014). Fluctuations in surface $\mathrm{pH}$ of maturing rat incisor enamel are a result of cycles of $\mathrm{H}(+)$-secretion by ameloblasts and variations in enamel buffer characteristics. Bone 60, 227-234. doi: 10.1016/j.bone.2013.12.018

Davideau, J. L., Papagerakis, P., Hotton, D., Lezot, F., and Berdal, A. (1996). In situ investigation of vitamin D receptor, alkaline phosphatase, and osteocalcin gene expression in oro-facial mineralized tissues. Endocrinology 137, 3577-3585.

DenBesten, P. K., Machule, D., Zhang, Y., Yan, Q., and Li, W. (2005). Characterization of human primary enamel organ epithelial cells in vitro. Arch. Oral Biol. 50, 689-694. doi: 10.1016/j.archoralbio.2004.12.008

Descroix, V., Kato, S., Lézot, F., and Berdal, A. (2010). Physiopathology of dental rickets in vitamin D receptor-ablated mice. J. Dent. Res. 89, 1427-1432. doi: 10.1177/0022034510379603

Dhamija, S., and Krebsbach, P. H. (2001). Role of Cbfal in ameloblastin gene transcription. J. Biol. Chem. 276, 35159-35164. doi: 10.1074/jbc.M01 0719200

Dodig, M., Kronenberg, M. S., Bedalov, A., Kream, B. E., Gronowicz, G., Clark, S. H., et al. (1996). Identification of a TAAT-containing motif required for high level expression of the COL1A1 promoter in differentiated osteoblasts of transgenic mice. J. Biol. Chem. 271, 16422-16429.

Ferrer, V. L., Maeda, T., and Kawano, Y. (2005). Characteristic distribution of immunoreaction for estrogen receptor alpha in rat ameloblasts. Anat. Rec. A Discov. Mol. Cell. Evol. Biol. 284, 529-536. doi: 10.1002/ar.a.20190

Fukumoto, S., Kiba, T., Hall, B., Iehara, N., Nakamura, T., Longenecker, G., et al. (2004). Ameloblastin is a cell adhesion molecule required for maintaining the differentiation state of ameloblasts. J. Cell Biol. 167, 973-983. doi: 10.1083/jcb.200409077

Gehring, W. J., Qian, Y. Q., Billeter, M., Furukubo-Tokunaga, K., Schier, A. F., Resendez-Perez, D., et al. (1994). Homeodomain-DNA recognition. Cell 78, 211-223. doi: 10.1016/0092-8674(94)90292-5

Golonzhka, O., Metzger, D., Bornert, J. M., Bay, B. K., Gross, M. K., Kioussi, C., et al. (2009). Ctip2/Bcl11b controls ameloblast formation during mammalian odontogenesis. Proc. Natl. Acad. Sci. U.S.A. 106, 4278-4283. doi: 10.1073/pnas.0900568106

Houari, S., Wurtz, T., Ferbus, D., Chateau, D., Desombz, A., Berdal, A., et al. (2014). Asporin and the mineralization process in fluoride-treated rats. J. Bone Min. Res. 29, 1446-1455. doi: 10.1002/jbmr.2153

Houzelstein, D., Cohen, A., Buckingham, M. E., and Robert, B. (1997). Insertional mutation of the mouse Msxl homeobox gene by an nlacZ reporter gene. Mech. Dev. 65, 123-133.

Israsena, N., and Kessler, J. A. (2002). Msx2 and p21(CIP1/WAF1) mediate the proapoptotic effects of bone morphogenetic protein- 4 on ventricular zone progenitor cells. J. Neurosci. Res. 69, 803-809. doi: 10.1002/ jnr. 10362

Jedeon, K., De la Dure-Molla, M., Brookes, S. J., Loiodice, S., Marciano, C., Kirkham, J., et al. (2013). Enamel defects reflect perinatal exposure to bisphenol A. Am. J. Pathol. 183, 108-118. doi: 10.1016/j.ajpath.2013.04.004 
Jacques, J., Hotton, D., De la Dure-Molla, M., Kulkarni, A. B., and Gibson, C., Petit, S., et al. (2014). Tracking endogenous amelogenin and ameloblastin in vivo. PLoS ONE 9:e99626. doi: 10.1371/journal.pone.0099626

Jiang, N., Zhou, J., Chen, M., Schiff, M. D., Lee, C. H., Kong, K., et al. (2014). Postnatal epithelium and mesenchyme stem/progenitor cells in bioengineered amelogenesis and dentinogenesis. Biomaterials 35, 2172-2180. doi: 10.1016/j.biomaterials.2013.11.061

Jiang, S. Y., and Wang, J. T. (2010). Msx2 alters the timing of retinal ganglion cells fate commitment and differentiation. Biochem. Biophys. Res. Commun. 395, 524-529. doi: 10.1016/j.bbrc.2010.04.058

Lacruz, R. S., Hacia, J. G., Bromage, T. G., Boyde, A., Lei, Y., Xu, Y., et al. (2012a). The circadian clock modulates enamel development. J. Biol. Rhythms 27, 237-245. doi: 10.1177/0748730412442830

Lacruz, R. S., Smith, C. E., Bringas, P. Jr., Chen, Y. B., Smith, S. M., Snead, M. L., et al. (2012b). Identification of novel candidate genes involved in mineralization of dental enamel by genome-wide transcript profiling. J. Cell. Physiol. 227, 2264-2275. doi: 10.1002/jcp.22965

Lee, H. K., Lee, D. S., Ryoo, H. M., Park, J. T., Park, S. J., Bae, H. S., et al. (2010). The odontogenic ameloblast-associated protein (ODAM) cooperates with RUNX2 and modulates enamel mineralization via regulation of MMP-20. J. Cell. Biochem. 111, 755-767. doi: 10.1002/jcb.22766

Lee, H., Quinn, J. C., Prasanth, K. V., Swiss, V. A., Economides, K. D., Camacho, M. M., et al. (2006). PIAS1 confers DNA-binding specificity on the Msx1 homeoprotein. Genes Dev. 20, 784-794. doi: 10.1101/gad.1392006

Lézot, F., Descroix, V., Mesbah, M., Hotton, D., Blin, C., Papagerakis, P., et al. (2002). Cross-talk between Msx/Dlx homeobox genes and vitamin D during tooth mineralization. Connect. Tissue Res. 43, 509-514. doi: 10.1080/03008200290000583

Lézot, F., Thomas, B., Greene, S. R., Hotton, D., Yuan, Z. A., Castaneda, B., et al. (2008). Physiological implications of DLX homeoproteins in enamel formation. J. Cell. Physiol. 216, 688-697. doi: 10.1002/jcp.21448

Li, X., Florez, S., Wang, J., Cao, H., and Amendt, B. A. (2013). Dact2 represses PITX2 transcriptional activation and cell proliferation through Wnt/betacatenin signaling during odontogenesis. PLoS ONE 8:e54868. doi: 10.1371/journal.pone. 0054868

Li, X., Venugopalan, S. R., Cao, H., Pinho, F. O., Paine, M. L., Snead, M. L., et al. (2014). A model for the molecular underpinnings of tooth defects in Axenfeld-Rieger syndrome. Hum. Mol. Genet. 23, 194-208. doi: 10.1093/hmg/ ddt411

Liu, Y. H., Kundu, R., Wu, L., Luo, W., Ignelzi, M. A. Jr., Snead, M. L., et al. (1995). Premature suture closure and ectopic cranial bone in mice expressing Msx2 transgenes in the developing skull. Proc. Natl. Acad. Sci. U.S.A. 92, 6137-6141.

Maas, R., and Bei, M. (1997). The genetic control of early tooth development. Crit. Rev. Oral Biol. Med. 8, 4-39.

Mackenzie, A., Ferguson, M. W., and Sharpe, P. T. (1992). Expression patterns of the homeobox gene, Hox-8, in the mouse embryo suggest a role in specifying tooth initiation and shape. Development 115, 403-420.

Mackenzie, A., Leeming, G. L., Jowett, A. K., Ferguson, M. W., and Sharpe, P. T. (1991). The homeobox gene Hox 7.1 has specific regional and temporal expression patterns during early murine craniofacial embryogenesis, especially tooth development in vivo and in vitro. Development 111, 269-285.

Mainguy, G., Koster, J., Woltering, J., Jansen, H., and Durston, A. (2007). Extensive polycistronism and antisense transcription in the mammalian Hox clusters. PLoS ONE 2:e356. doi: 10.1371/journal.pone.0000356

Marazzi, G., Wang, Y., and Sassoon, D. (1997). Msx2 is a transcriptional regulator in the BMP4-mediated programmed cell death pathway. Dev. Biol. 186, 127-138.

Matsumoto, A., Harada, H., Saito, M., and Taniguchi, A. (2011). Induction of enamel matrix protein expression in an ameloblast cell line co-cultured with a mesenchymal cell line in vitro. In Vitro Cell. Dev. Biol. Anim. 47, 39-44. doi: 10.1007/s11626-010-9362-7

Mirzayans, F., Lavy, R., Penner-Chea, J., and Berry, F. B. (2012). Initiation of early osteoblast differentiation events through the direct transcriptional regulation of Msx2 by FOXC1. PLoS ONE 7:e49095. doi: 10.1371/journal.pone.0049095

Mitsiadis, T. A., Tucker, A. S., De Bari, C., Cobourne, M. T., and Rice, D. P. (2008). A regulatory relationship between Tbxl and FGF signaling during tooth morphogenesis and ameloblast lineage determination. Dev. Biol. 320, 39-48. doi: 10.1016/j.ydbio.2008.04.006

Molla, M., Descroix, V., Aïoub, M., Simon, S., Castañeda, B., Hotton, D., et al. (2010). Enamel protein regulation and dental and periodontal physiopathology in MSX2 mutant mice. Am. J. Pathol. 177, 2516-2526. doi: 10.2353/ajpath.2010.091224

Muto, T., Miyoshi, K., Horiguchi, T., and Noma, T. (2012). Dissection of morphological and metabolic differentiation of ameloblasts via ectopic SP6 expression. J. Med. Invest. 59, 59-68. doi: 10.2152/jmi.59.59

Nassif, A., Senussi, I., Méary, F., Loiodice, S., Hotton, D., Robert, B., et al. (2014). Msx1 role in craniofacial bone morphogenesis. Bone 66, 96-104. doi: 10.1016/j.bone.2014.06.003

Ogawa, T., Kapadia, H., Feng, J. Q., Raghow, R., Peters, H., and D’Souza, R. N. (2006). Functional consequences of interactions between Pax9 and Msx1 genes in normal and abnormal tooth development. J. Biol. Chem. 281, 18363-18369. doi: 10.1074/jbc.M601543200

Onishi, T., Shintani, S., Wakisaka, S., and Ooshima, T. (2008). Relationship of vitamin D with calbindin D9k and D28k expression in ameloblasts. Arch. Oral Biol. 53, 117-123. doi: 10.1016/j.archoralbio.2007.09.009

Petit, S., Meary, F., Pibouin, L., Jeanny, J. C., Fernandes, I., Poliard, A., et al. (2009). Autoregulatory loop of Msxl expression involving its antisense transcripts. $J$. Cell. Physiol. 220, 303-310. doi: 10.1002/jcp.21762

Sahlberg, C., Pohjanvirta, R., Gao, Y., Alaluusua, S., Tuomisto, J., and Lukinmaa, P. L. (2002). Expression of the mediators of dioxin toxicity, aryl hydrocarbon receptor (AHR) and the AHR nuclear translocator (ARNT), is developmentally regulated in mouse teeth. Int. J. Dev. Biol. 46, 295-300.

Satokata, I., and Maas, R. (1994). Msx1 deficient mice exhibit cleft palate and abnormalities of craniofacial and tooth development. Nat. Genet. 6, 348-356.

Satokata, I., Ma, L., Ohshima, H., Bei, M., Woo, I., Nishizawa, K., et al. (2000). Msx2 deficiency in mice causes pleiotropic defects in bone growth and ectodermal organ formation. Nat. Genet. 24, 391-395. doi: 10.1038/74231

Shao, J. S., Cheng, S. L., Pingsterhaus, J. M., Charlton-Kachigian, N., Loewy, A. P., and Towler, D. A. (2005). Msx2 promotes cardiovascular calcification by activating paracrine Wnt signals. J. Clin. Invest. 115, 1210-1220. doi: 10.1172/ JCI24140

Sharpe, P. T. (1995). Homeobox genes and orofacial development. Connect. Tissue Res. 32, 17-25. doi: 10.3109/03008209509013701

Shirasawa, T., Sakamoto, K., and Tkahashi, H. (1994). Molecular cloning and evolutional analysis of a mammalian homologue of the Distal-less 3 (Dlx-3) homeobox gene. FEBS Lett. 351, 380-384. doi: 10.1016/0014-5793(94)00896-5

Simmer, J. P., Richardson, A. S., Wang, S. K., Reid, B. M., Bai, Y., Hu, H. et al. (2014). Ameloblast transcriptome changes from secretory to maturation stages. Connect Tissue Res. 55(Suppl. 1), 29-32. doi: 10.3109/03008207.2014.923862

Simon, Y., Marchadier, A., Riviere, M. K., Vandamme, K., Koenig, F., Lezot, F., et al. (2014). Cephalometric assessment of craniofacial dysmorphologies in relation with Msx2 mutations in mouse. Orthod. Craniofac. Res. 17, 92-105. doi: 10.1111/ocr.12035

Snead, M. L., Luo, W., Lau, E. C., and Slavkin, H. C. (1988). Spatial- and temporalrestricted pattern for amelogenin gene expression during mouse molar tooth organogenesis. Development 104, 77-85.

Sonoda, A., Iwamoto, T., Nakamura, T., Fukumoto, E., Yoshizaki, K., Yamada, A., et al. (2009). Critical role of heparin binding domains of ameloblastin for dental epithelium cell adhesion and ameloblastoma proliferation. J. Biol. Chem. 284, 27176-27184. doi: 10.1074/jbc.M109.033464

Stahl, J., Nakano, Y., Kim, S. O., Gibson, C. W., Le, T., and DenBesten, P. (2013). Leucine rich amelogenin peptide alters ameloblast differentiation in vivo. Matrix Biol. 32, 432-442. doi: 10.1016/j.matbio.2013. 05.004

Thesleff, I. (2003). Epithelial-mesenchymal signalling regulating tooth morphogenesis. J. Cell Sci. 116, 1647-1648. doi: 10.1242/jcs.00410

Thesleff, I. (2006). The genetic basis of tooth development and dental defects. Am. J. Med. Genet. A 140, 2530-2535. doi: 10.1002/ajmg.a.31360

Tian, H., Lv, P., Ma, K., Zhou, C., and Gao, X. (2010). Beta-catenin/LEF1 activated enamelin expression in ameloblast-like cells. Biochem. Biophys. Res. Commun. 398, 519-524. doi: 10.1016/j.bbrc.2010.06.111

Vastardis, H., Karimbux, N., Guthua, S. W., Seidman, J. G., and Seidman, C. E. (1996). A human MSX1 homeodomain missense mutation causes selective tooth agenesis. Nat. Genet. 13, 417-421.

Venugopalan, S. R., Li, X., Amen, M. A., Florez, S., Gutierrez, D., Cao, H., et al. (2011). Hierarchical interactions of homeodomain and forkhead transcription factors in regulating odontogenic gene expression. J. Biol. Chem. 286, 21372-21383. doi: 10.1074/jbc.M111.252031 
Wang, J., and Abate-Shen, C. (2012). Transcriptional repression by the Msx1 homeoprotein is associated with global redistribution of the H3K27me3 repressive mark to the nuclear periphery. Nucleus 3, 155-161. doi: 10.4161/ nucl. 19477

Wang, Y., Kong, H., Mues, G., and D'Souza, R. (2011). Msx1 mutations: how do they cause tooth agenesis? J. Dent. Res. 90, 311-316. doi: 10.1177/0022034510387430

Wu, L. Y., Li, M., Hinton, D. R., Guo, L., Jiang, S., Wang, J. T., et al. (2003). Microphthalmia resulting from MSX2-induced apoptosis in the optic vesicle. Invest. Ophthalmol. Vis. Sci. 44, 2404-2412. doi: 10.1167/iovs. 02-0317

Xu, L., Matsumoto, A., Sasaki, A., Harada, H., and Taniguchi, A. (2010). Identification of a suppressor element in the amelogenin promoter. J. Dent. Res. 89, 246-251. doi: 10.1177/0022034509355144

Xu, Y., Zhou, Y. L., Erickson, R. L., MacDougald, O. A., and Snead, M. L. (2007a). Physical dissection of the CCAAT/enhancer-binding protein alpha in regulating the mouse amelogenin gene. Biochem. Biophys. Res. Commun. 354, 56-61. doi: 10.1016/j.bbrc.2006.12.182

Xu, Y., Zhou, Y. L., Gonzalez, F. J., and Snead, M. L. (2007b). CCAAT/enhancerbinding protein delta (C/EBPdelta) maintains amelogenin expression in the absence of C/EBPalpha in vivo. J. Biol. Chem. 282, 29882-29889. doi: 10.1074/jbc.M702097200

Xu, Y., Zhou, Y. L., Luo, W., Zhu, Q. S., Levy, D., MacDougald, O. A., et al. (2006). NF-Y and CCAAT/enhancer-binding protein alpha synergistically activate the mouse amelogenin gene. J. Biol. Chem. 281, 16090-16098. doi: 10.1074/jbc.M510514200

Yamashiro, T., Tummers, M., and Thesleff, I. (2003). Expression of bone morphogenetic proteins and Msx genes during root formation. J. Dent. Res. 82, 172-176. doi: $10.1177 / 154405910308200305$

Yanagawa, T., Itoh, K., Uwayama, J., Shibata, Y., Yamaguchi, A., Sano, T., et al. (2004). Nrf2 deficiency causes tooth decolourization due to iron transport disorder in enamel organ. Genes Cells 9, 641-651. doi: 10.1111/j.13569597.2004.00753.x

Yasukawa, M., Ishida, K., Yuge, Y., Hanaoka, M., Minami, Y., Ogawa, M., et al. (2013). Dpysl4 is involved in tooth germ morphogenesis through growth regulation, polarization and differentiation of dental epithelial cells. Int. J. Biol. Sci. 9, 382-390. doi: 10.7150/ijbs.5510

Yoshiba, N., Yoshiba, K., Aberdam, D., Meneguzzi, G., Perrin-Schmitt, F., Stoetzel, C., et al. (1998). Expression and localization of laminin-5 subunits in the mouse incisor. Cell Tissue Res. 292, 143-149.

Yoshizawa, T., Takizawa, F., Iizawa, F., Ishibashi, O., Kawashima, H., Matsuda, A., et al. (2004). Homeobox protein MSX2 acts as a molecular defense mechanism for preventing ossification in ligament fibroblasts.
Mol. Cell. Biol. 24, 3460-3472. doi: 10.1128/MCB.24.8.3460-3472. 2004

Zhang, H., Catron, K. M., and Abate-Shen, C. (1996). A role for the Msx-1 homeodomain in transcriptional regulation: residues in the $\mathrm{N}$-terminal arm mediate TATA binding protein interaction and transcriptional repression. Proc. Natl. Acad. Sci. U.S.A. 93, 1764-1769.

Zhang, H., Hu, G., Wang, H., Sciavolino, P., Iler, N., Shen, M. M., et al. (1997). Heterodimerization of Msx and Dlx homeoproteins results in functional antagonism. Mol. Cell. Biol. 17, 2920-2932.

Zhang, Y., Li, W., Chi, H. S., Chen, J., and Denbesten, P. K. (2007). JNK/c-Jun signaling pathway mediates the fluoride-induced down-regulation of MMP-20 in vitro. Matrix Biol. 26, 33-641. doi: 10.1016/j.matbio.2007.06.002

Zheng, L., Seon, Y. J., Mourão, M. A., Schnell, S., Kim, D., Harada, H., et al. (2013). Circadian rhythms regulate amelogenesis. Bone 55, 158-165. doi: 10.1016/j.bone.2013.02.011

Zhou, H. M., Nichols, A., Wohlwend, A., Bolon, I., and Vassalli, J. D. (1999). Extracellular proteolysis alters tooth development in transgenic mice expressing urokinase-type plasminogen activator in the enamel organ. Development 126, 903-912.

Zhou, Y. L., Lei, Y., and Snead, M. L. (2000). Functional antagonism between Msx2 and CCAAT/enhancer-binding protein alpha in regulating the mouse amelogenin gene expression is mediated by protein-protein interaction. J. Biol. Chem. 275, 29066-29075. doi: 10.1074/jbc.M002031200

Zhou, Y. L., and Snead, M. L. (2000). Identification of CCAAT/enhancer-binding protein alpha as a transactivator of the mouse amelogenin gene. J. Biol. Chem. 275, 12273-12280. doi: 10.1074/jbc.275.16.12273

Conflict of Interest Statement: The authors declare that the research was conducted in the absence of any commercial or financial relationships that could be construed as a potential conflict of interest.

Received: 11 June 2014; accepted: 08 December 2014; published online: 05 January 2015.

Citation: Babajko S, de La Dure-Molla M, Jedeon K and Berdal A (2015) MSX2 in ameloblast cell fate and activity. Front. Physiol. 5:510. doi: 10.3389/fphys.2014.00510 This article was submitted to Craniofacial Biology, a section of the journal Frontiers in Physiology.

Copyright (c) 2015 Babajko, de La Dure-Molla, Jedeon and Berdal. This is an openaccess article distributed under the terms of the Creative Commons Attribution License (CC BY). The use, distribution or reproduction in other forums is permitted, provided the original author(s) or licensor are credited and that the original publication in this journal is cited, in accordance with accepted academic practice. No use, distribution or reproduction is permitted which does not comply with these terms. 